\title{
Indonesian Ocean Policy: Paradigm Shift in Strengthening Ocean Governance
}

\author{
Ade Maman Suherman ${ }^{* *} \&$ Aryuni Yuliantiningsih ${ }^{* * *}$ \\ \& Noer Indriati ${ }^{* * * *} \&$ Wismaningsih ${ }^{* * * *} \&$ Hazmi Rusli ${ }^{* * * * *}$
}

The Indonesian Ocean Policy (IOP) is a new milestone in managing its oceans since Indonesia ratified the UNCLOS 35 years ago. Indonesia underwent several paradigm shifts in strengthening ocean governance from 1957 to 2014. This research aims to analyse three paradigm shifts in strengthening ocean governance in Indonesia. The research revealed that the milestone of the first shift was the 1957 Djuanda Declaration, recognised by the UNCLOS in 1982, regarding the concept of an archipelago state, called the 'ocean space paradigm.' The second, which occurred in the Reformation period (1998-2014) was called the Ocean Development paradigm, while the third paradigm shift was after President Jokowi launched Indonesia's vision as a Global

* The research and publication were supported by the International Research Collaboration Grant of Universitas Jenderal Soedirman (Contract Number 116/UN23/PT.01.05/2020).

All the websites cited in this article were last visited on October 17, 2020.

** Professor of International Law at Jenderal Soedirman University. S.H. (UNSOED), MSc. (Groningen), Ph.D. (U. Indonesia) ORCID: https://orcid.org/0000-0001-6888-8972. The author may be contacted at ade.suherman@unsoed. ac.id/Address: Law Faculty, UNSOED, J1. H.R. Bunyamin 708, Puwokerto, Indonesia.

*** Corresponding author. Associate Professor of International Law at Faculty of Law UNSOED S.H. (UNSOED), M.H. (UNPAD, Bandung), PhD. (Universitas Sebelas Maret). ORCID: https://orcid.org/0000-0002-0761-5345. The author may be contacted at aryuni.yuliantiningsih@unsoed.ac.id/Address: Law Faculty, UNSOED, Jl. H.R. Bunyamin 708, Puwokerto, Indonesia.

**** Associate Professor of International Law at Faculty of Law UNSOED, S.H/MH. (UNDIP), PhD. (UNPAD). ORCID: https://orcid.org/0000-0002-4731-7537. The author may be contacted at: noer.indriati@unsoed.ac.id/Address: Law Faculty, UNSOED, Jl. H.R. Bunyamin 708, Puwokerto, Indonesia.

***** Assistant Professor of International Law at Faculty of Law UNSOED, S.H. (UNSOED), M.H. (UNPAD). ORCID: https://orcid.org/0000-0001-6413-2174. The author may be contacted at wismaningsih@unsoed.ac.id/Address: Law Faculty, UNSOED, Jl. H.R. Bunyamin 708, Puwokerto, Indonesia.

****** Associate Professor in International Law at Universiti Sains Islam Malaysia. LL.B. (IIUM), LL.M. (IIUM), Ph.D. (Wollongong). ORCID: https://orcid.org/0000-0003-0099-6875. The author may be contacted at: hazmi.rusli.@usim. edu.my/Address: Law Faculty of Syariah and Law, USIM, Bandar Baru Nilai, 71800 nilai, Negeri Sembilan, Malaysia. 
Maritime Fulcrum. This third paradigm shift was also associated with the emergence of the IOP, which contributes to national development and pays comprehensive attention to the constellation of relations between the countries in Asia and various initiatives in the region.

\section{Keywords}

Indonesian Ocean policy, Ocean Governance, Paradigm Shift, UNCLOS, Djuanda Declaration

\section{Introduction}

Indonesia as the biggest archipelago state comprises 2.8 million square kilometres of water (including 92,877 square kilometres of inland waters) and 1,826,440 square kilometres of land. ${ }^{1}$ The Indonesian sea has enormous natural and environmental resources whose potential can be utilised. ${ }^{2}$ Indonesia's status as an archipelago has been recognised under the 1982 United Nations Convention on the Law of the Sea (UNCLOS) which was ratified by Indonesian legislature through Law No. 17 of $1985 .^{3}$

One of the problems faced by Indonesia over its maritime domain was the absence of a single comprehensive ocean regulation for many years. There was instead a corpus of over a dozen laws that gave different ministries and agencies specific responsibilities at sea. Development activities were scattered, originating from various central government ministries and agencies, and dissipating into different levels of regional administration without a clear roadmap, leading to disappointing results and inefficiency. Institutional competition was a particular hazard to law enforcement at sea. The seriousness of the situation led to increasing calls for a more integrated policy on managing Indonesia's seas. ${ }^{4}$

Dirhamsyah explains that maritime law enforcement in Indonesia is confronted by several challenges, including lack of funding, facilities, trained personnel, interagency coordinating mechanisms, environmental awareness, integrated laws,

1 See generally R. Cribb \& M. Ford, Indonesia Beyond the Wateras Edge: Managing an Archipelagic State 1-247 (2009).

2 K. Bhaka, Indonesia s Natural Resources and Green Development (May 26, 2019), https://borgenproject.org/ indonesias-natural-resources-and-green-development.

3 S. Butt, The Position of International Law within the Indonesian Legal System, 28 Emory InT'L L. Rev. 1-28 (2014).

4 Dewi \& Fortuna Anwar, The Emergence of Indonesia's Ocean Policy, RSIS CommENT. (2018). 
coordination, political will and commitment. ${ }^{5}$

Based on past experiences, the Indonesian government established a momentum from the beginning in its formulation of the UNCLOS and the paradigm shift of national ocean development since Indonesia's independence in 1945 to the present. In 2014, after 35 years since Indonesia ratified the UNCLOS, Indonesia enacted Law No. 32 of 2014 on Maritime Affairs as an umbrella legislation on Indonesian ocean governance. ${ }^{6}$ Strengthening Indonesia's maritime identity was one of the campaign pledges put forward by President Joko Widodo (called "Jokowi"), which he concretized with the plan to make Indonesia a Global Maritime Fulcrum (GMF) on October 20, 2014. ${ }^{7}$

On February 20, 2017, Jokowi signed Presidential Decree Number 16 of 2017 concerning Indonesian Ocean Policy (IOP) to realize GMF. It would be the primary reference point for all programmes and activities related to Indonesia's maritime domain. The goal of the IOP is to achieve the GMF Vision for Indonesia as a sovereign, advanced, independent, and strong maritime nation with the ability to make positive contributions toward peace and security in the region as well as the world. ${ }^{8}$

The IOP also states that the GMF vision should take into account and synergize with various regional initiatives so long as they are in line with Indonesia's national interests and can contribute to peace. Following the IOP, the international community is also paying close attention to global ocean governance issues, specifically the 14th target of Sustainable Development Goals (SDGs) titled "Life below Water.",

The research underlying this paper sums up Indonesia's paradigm shift in formulating the national ocean policy and examines its contribution to regional and global ocean governance. The article consists of five parts including the Introduction and Conclusion. Part two will examine the paradigm shift in Indonesia's ocean policy from the Djuanda Declaration of 1957 and expands to the emerging vision of the GMF in 2014. Part three will analyse the emergence of IOP as a form of Indonesian national aspiration. Part four will investigate Indonesia's role in regional initiatives on global ocean governance.

5 Dirhamsyah, Maritime Law Enforcement and Compliance in Indonesia: Problems and Recommendations, MAR. STUD. 1-16(2005).

6 Peni Susetyorini, Indonesian Marine Policy in UNCLOS 1982 Perspective [Kebijakan Kelautan Indonesia Dalam Perspektif Unclos 1982], 48 Masal. HuK. 164 (2019).

Supra note 4, at. 2.

$8 \quad$ Id.

9 UNEP, Sustainable Development Goal No. 14: Life below Water, https://www.unenvironment.org/explore-topics/ sustainable-development-goals/why-do-sustainable-development-goals-matter/goal-14. 


\section{Paradigm Shift in Strengthening Indonesia's Ocean Governance}

\section{A. Ocean Governance in Indonesia in 1957-1998}

The history of Indonesia's jurisdiction over its maritime territory commences from Indonesia's Proclamation of Independence on August 17, 1945 to the Djuanda Declaration. The Declaration was made by its namesake, the then Prime Minister Ir. H. Djuanda Kartawidjaja, on December 13, 1957 which declared Indonesia is an archipelago State to the international community. ${ }^{10}$

The Djuanda Declaration was the first step in a long and complicated struggle for international recognition of Indonesia's sovereignty over its maritime territory. ${ }^{11}$ The Declaration was a claim and effort to recognise the sovereignty of the Indonesian archipelago by securing its international legal status. Before the Djuanda Declaration, the territory of the Republic of Indonesia referred to the 1939 Netherlands Indies Ordinance, namely the Zeeën en Maritieme Kringen Ordonantie 1939 (TZMKO). Indonesia introduced an enlarged concept of the territorial sea boundary for an island nation, extending the distancefrom 3 to 12 nautical miles (nm). ${ }^{12}{ }^{13}$ In the UN Conference on the Law of the Sea I (1958) and II (1960), Indonesia had fought for a $12 \mathrm{~nm}$ territorial sea but failed. Through rigorous diplomatic efforts, Indonesia, with other island nations, succeeded in obtaining their "island nation" status and a territorial sea jurisdiction of $12 \mathrm{~nm}$ in the Third UN Conference on the Law of the Sea (1982).

After the Djuanda Declaration, several regulations relating to maritime affairs emerged, including: the Law No. 4/Prp/1960 concerning Indonesian waters; Law No. 1/1973 on the Indonesian continental shelf; Law No. 5 of 1983 on Exclusive Economic Zone; Law No. 17 of 1985 on ratification of the UNCLOS; and Law No. 6 of 1996 on Indonesian Waters. These policies and regulations confirm the jurisdiction of Indonesian waters.

10 Damos Agusman \& Gulardi Nurbintoro, The Archipelagic-State Concept a Quid pro Quo, JAKarta Post, Dec. 14, 2019, https:/www.thejakartapost .com/academia/2019/12/ 14/the-archipelagic-state-concept-a-quid-pro-quo.html.

11 L. Nolde, Sovereignty and the Sea: How Indonesia Became an Archipelagic State, by John G. Butcher and R.E. Elson, 174 BJ. Human. \& Soc. Sci. Southeast Asia 81-3 (2018).

12 Pemerintah Republik Indonesia, Tambahan Lembaran Negara RI No. 5416, 54166 (2013), http://www.djpp.kemenkuham. go.id.

13 J. Draper, The Indonesian Archipelagic State Doctrine and Law of the Sea: Territorial Grab or Justifiable Necessity, 11 INT'L LAW. 143 (1977). 
The Djuanda Declaration marked the first paradigm shift in strengthening Indonesian ocean governance, leading to the statement affirming Indonesia as an archipelago State with a territory extending outward to $12 \mathrm{~nm}$. In addition, the Declaration was the starting point for the emergence of the Wawasan Nusantara (Archipelagic Outlook) concept. Wawasan Nusantara encapsulates the Indonesian people's view of their territory and environment, prioritizing regional unity and unity in the administration of the life of the community, nation and state. ${ }^{14}$ The authors are in agreement with Purwaka's opinion that the first paradigm is called the Ocean Space Paradigm. ${ }^{15}$

Further, the Wawasan Nusantara is stipulated in General Guidelines of States Policy or Garis-Garis Besar Haluan Negara ("GBHN"). The GBHN adopted Wawasan Nusantara as the basis for all national development actions, including those conducting the ocean space development program. Before 1998, the GBHN was renewed every five years. During the Suharto government (also known as New Order Era) from the 1970s to 1998, the Wawasan Nusantara doctrine continued to be socialised through seminars, workshops, trainings and projects throughout the country. ${ }^{16}$ During the New Order period (1966-98), however, the government paid little attention to national ocean development. The Suharto government's priorities were largely landbased and focused on densely populated islands in western Indonesia. ${ }^{17}$

\section{B. Indonesian Ocean Governance (1998-2014)}

The New Order period ended in 1998, and was replaced by the Reformation Order. During the reform period, the government began to pay attention to ocean development. In 1999, President Abdurrahman Wahid began to focus on marine affairs and thus formed the Department of Marine Exploration and Fisheries in the period between 1999 and 2004. In 2000, the name of the Department was changed to the Department of Marine Affairs and Fisheries. In 2007, President Susilo Bambang Yudhoyono formulated a consultative body, called the "Dewan Kelautan Indonesia" (Indonesian Maritime Council), to help formulate a general policy on ocean affairs. ${ }^{18}$

14 E. Laksmana \& R. Supriyanto, Abandoned at Sea: The Tribunal Ruling and Indonesia's Missing Archipelagic Foreign Policy, 10(2) Asian Pol. \& Pol'y 302 (2018).

15 T. Purwaka, Paradigm Shift in the Implementation of the Law of the Sea in Indonesia, 8(1) INDON. J. INT'L L. 115 (2010).

16 Id.

17 Kementerian PPN/ Bappenas, Mainstreaming Ocean Policy Concept Into the National Development Plan [Konsep Mainstreaming Ocean Policy Kedalam Rencana Pembangunan Nasional] 360 (2014).

18 Presidential Decree No 21 of 2007 [Keputusan Presiden Republik Indonesia Nomor 21 tahun 2007], http://jdih.kkp. go.id/peraturan/keppres-2007-21.pdf. 
Furthermore, the government enacted a marine management policy for decentralisation, which meant the regional government was given authority to manage the sea to the $12 \mathrm{~nm}$, based on Law No. 23 of 2004 concerning Local Government. The Law No. 23 aimed to strengthen local government jurisdiction over the ocean space of the Indonesian archipelago. The Law No. 23 was amended in 2014 concerning Local Government.

The emergence of a paradigm to promote development based on marine and fisheries resources as its driving force is reflected in the Law No. 17 of 2007 on the Long-Term National Development Plan (LTNDP). One of its missions is: "Realising Indonesia to become an independent, strong, developed, and island nation conscious of its national interests." ${ }^{, 19}$

In 2009, the Department of Maritime Affairs and Fisheries became its own 'Ministry.' The formation of this Ministry had the first positive impact. There was a paradigm shift in this course. First, the Indonesian people got to know that Indonesia had large marine resources which could become a force for Indonesia's economic development if properly managed. Second, they became aware that Indonesia is a unitary state consisting of large and small islands, so that the government must emphasize economic, political and territorial unity under state power in managing the maritime development. ${ }^{20}$

President Yudhoyono signed the Law No. 32 of 2014 on Marine Affairs on October 17, 2014, just a few days before the end of his second and final tenure as head of State. The move brought together salient elements scattered in different legislations pertaining to the management and development of Indonesia's maritime domain. The Law No. 32 became Indonesia's umbrella act for managing maritime territory after 35 years of ratifying the UNCLOS. ${ }^{21}$

We propose that the second paradigm shift related to ocean governance occurred in the Reformation Period and is called the Ocean Development Paradigm. This paradigm is marked by a shift from land to ocean-based development. The ocean development paradigm is characterised by the formation of ministries and institutions that manage marine and fisheries' affairs.

19 Vision and Long-Term Development Directions [Visi dan Arah Pembangunan Jangka Panjang 2005-2025], https:// www.bappenas.go.id/files/1814/2057/0437/RPJP_2005-2025.pdf.

20 Ministry of Marine Affairs and Fisheries of the Republic of Indonesia [Kementrian Kelautan dan Perikanan Republik Indonesia], TRIBUNE News WIKI (Oct. 22, 2019) https://www.tribunnewswiki.com/2019/10/22/kementerian-kelautandan-perikanan-republik-indonesia.

21 Law No. 32 of 2014. 


\section{Indonesian Ocean Governance (2014-20)}

In 2014, Joko Widodo was elected as Indonesia's seventh president. In the appointment speech on October 20, 2014, he said: "We have to work hard to restore Indonesia as a maritime country. The oceans, the seas, the bays and the straits are the future of our civilization. We have far too long turned our back on the seas, the oceans, the straits and the bays. It's time to restore everything so that 'jalesveva jayamahe" (in the sea we will triumph)."22 President Joko Widodo launched a new vision in the maritime field, marking the sea as the nation's future and its very strategic goal of making Indonesia as the GMF. The concept of the GMF is also mentioned in the East Asia Summit (EAS). When he was delivering a speech in November 2014, Jokowi elaborated on the notion by listing the five pillars of the maritime fulcrum. He outlined five missions that would act as the following pillars supporting the maritime-fulcrum doctrine.

1. Rebuilding Indonesia's maritime culture. Indonesia, as the largest archipelagic country with 18,000 islands, should recognise its oceans as part of its national identity and prosperity, which means that good ocean management determines Indonesia's future.

2. Maintaining and managing marine resources through the development of a sustainable fishing industry by sovereignty on the marine food sector.

3. Prioritising maritime connectivity and infrastructure development. The program includes developing the tourism industry, constructing sea highways along the coast of Java and developing the shipping industry.

4. Intensifying maritime diplomacy. This will be achieved by inviting partner countries to work together on maritime and marine issues to reduce and mediate disputes as well as conflict factors such as territorial disputes, illegal fishing, smuggling, piracy, violations of sovereignty and marine pollution.

5. Strengthening Indonesia's maritime defence capability. The aim is not merely to maintain Indonesia maritime sovereignty and its natural resources, but also to ensure the safety and peace of the region's maritime security. ${ }^{23}$

Indonesia's national development over the past several decades was considered to be more terrestrial oriented; therefore the maritime aspect received less political attention. The current government is shifting its paradigm to strike a balance between

22 See Full Text: Jokowi's Inauguration Speech (Oct. 20, 2014), https://www.rappler.com/world/regions/asia-pacific/ indonesia/72529-text-jokowi-inauguration-speech.

23 Md Agoes Aufiya, Indonesia's Global Maritime Fulcrum: Contribution in the Indo-Pacific Region, 16(2) Andalas J. INT'L STUD. 146 (2017). 
land and marine development. ${ }^{24}$

To realize Indonesia as GMF, Jokowi created the new Coordinating Ministry for Maritime Affairs, which mediates the Ministry for Maritime Affairs and Fishery, the Ministry of Transportation, the Ministry of Energy and Mineral Resources as well as the Ministry of Tourism, reflecting its economic thrust.

During the President Jokowi period there has been a third paradigm shift in managing Indonesia's ocean. This shift occurred with the launch of President Jokowi's vision of Indonesia as GMF. This vision can be understood in three meanings. First, GMF can be seen as an ideal that Indonesia wants to evolve into. The GMF idea is a great call to return to the identity of the Indonesian people or national identity as an archipelagic nation, which is expected to manifest in the form of Indonesia's unity, prosperity and dignity. ${ }^{25}$ The GMF vision is a milestone throughout the history of national policy formulation in Indonesia. ${ }^{26}$ Second, GMF can also be considered as a doctrine, which gives a sense of common purpose. President Jokowi continues to ask the Indonesian people to see themselves as a "GMF, a Power between Two Oceans." Third, the vision of GMF does not stop at the level of abstraction and conceptualization. It becomes operational upon the realization of President Jokowi's platform which contains a number of concrete agendas expected to be realised in his future administration such as the construction of the "Sea Highway" to ensure interisland connectivity.

\section{The Emergence of Indonesian Ocean Policy}

To appreciate Indonesia as a GMF, the Government issued Regulation No. 16 of 2017 concerning the Indonesian Ocean Policy ("IOP”). The IOP was adopted on Indonesia's Development Vision as stipulated in Law No. 17 of 2007 concerning the National Long-Term Development Plan (2005-25) and Law No. 32 of 2014 concerning Maritime Affairs.

Based on Article 1 of the President's regulation, the IOP is a general guideline

24 Bappenas, supra note 15.

25 Teddy Syamsuri, Now, world ocean geometry and Nushani [Visi Poros Maritim Dunia dan Konsepsi Wawasan Nusantara], MAR. NEws (online), Sept. 7, 2017, http://maritimnews.com/2017/09/visi-poros-maritim-dunia-dan-konsepsiwawasan-nusantara.

26 Damonz, Let's Realize the Global maritime Fulcrume with Maritime Education and Training [Ayo Wujudkan Poros maritim Dunia Bersama Diklat maritime], https://qubiz.net/ayo-wujudkan-poros-maritim-dunia-bersama-diklatmaritim-pembangunan. 
for marine policy and its implementation through programs and activities of ministries/institutions which are prepared to accelerate the implementation of GMF. There are two integral parts to the policy. The first is the main document on Indonesia's National Ocean Policy, which serves as an authoritative reference point for the implementation of maritime policy. It outlines a number of important aspects including Indonesia's sovereign rights in the maritime domain, challenges in fulfilling its grand maritime aspiration, and the objectives and underlying principles of the Ocean Policy. ${ }^{27}$

The roadmap of the IOP highlights seven policy pillars: Marine and Human Resources Development; Maritime Security, Law Enforcement and Safety at Sea; Ocean Governance and Institutions; Development of Maritime Economy; Ocean Space Management and Marine Protection; Maritime Culture; and Maritime Diplomacy. Each policy pillar is further broken down and altogether totals 76 policies/strategies. ${ }^{28}$

The second part of the regulatory framework is the IOP Action Plan. Essentially, the Action Plan translates the seven pillars into policy programmes, completing it with a detailed outline of policy priorities, strategies, aims and objectives. It sets out the ministries and institutions responsible for programme implementation, defines relevant institutions and stakeholders, and establishes the timeframe and funding sources. $^{29}$

There are five program priorities in the 2015-2019 National Action Plan that will be realised, namely:
a. Maritime Boundaries, Maritime Space and Maritime Diplomacy;
b. Maritime Industry and Marine Connectivity;
c. Natural Resource Industry, Marine services and marine environment management;
d. Marine defence and security; and
e. Maritime Culture ${ }^{30}$

The IOP is primarily domestically oriented. Most of the policy pillars and strategies are aimed at strengthening the protection and management of the Indonesian archipelago and maximizing the nation's economic potential. Its maritime domain

27 Indriati Kusumawardhani \& Arie Afriansyah, Marine Policy and Marine Foreign Policy of Indonesia [Kebiajakan Kelautan Indonesia dan Diplomasi Maritim], 41 Kertha PATRIKA 255 (2019).

28 Supra note 4 at 3.

29 Keoni Indrabayu Marzuki, Indonesia's National Sea Policy : Concretising the Global Maritime Fulcrum, RSIS Comment. No. 52 (2017).

30 Secretariat of the Cabinet of the Republic of Indonesia, Indonesian Ocean Policy Document [Inilah poin-poin Dokumen Kebijakan Kelautan Indonesia] (Mar.17, 2017), https://setkab.go.id/inilah-poin-poin-dokumen-kebijakan-kelautanindonesia. 
supplements Indonesia's overall economic development. Summing up, the paradigm shift in Indonesian ocean governance is presented in Table 1.

Table 1: Chronology of Paradigm Shifts in the Indonesian Ocean Governance

\begin{tabular}{|c|c|c|c|c|}
\hline No & Paradigm Shift & Period & Milestone & Legal foot-print \\
\hline 1 st & $\begin{array}{l}\text { Space ocean } \\
\text { paradigm }\end{array}$ & 1957-1998 & $\begin{array}{l}\text { Archipelagic outlook } \\
\text { (Wawasan Nusantara) } \\
\text { UNCLOS ratification }\end{array}$ & $\begin{array}{l}\text { - Djuanda Declaration } 1957 \\
\text { - Law no } 6 \text { of } 1960 \text { on } \\
\text { Indonesia's water } \\
\text { - Law no } 17 \text { of } 1985 \text { on s } \\
\text { UNCLOS ratification }\end{array}$ \\
\hline 2nd & $\begin{array}{l}\text { Ocean } \\
\text { development } \\
\text { paradigm } \\
\text { (from land-to } \\
\text { ocean-based } \\
\text { development) }\end{array}$ & $\begin{array}{c}\text { 1999-2014 } \\
\text { (Reform Period) }\end{array}$ & $\begin{array}{l}\text { Creating institutions } \\
\text { relating to marine } \\
\text { affairs } \\
\text { Ocean Management } \\
\text { by local government } \\
\text { Formulating } \\
\text { the ocean policy }\end{array}$ & $\begin{array}{l}\text { - Law No.32 of } 2004 \\
\text { - Law No } 17 \text { of } 2007 \\
\text { on Long-Term } \\
\text { Development Plan } \\
\text { - Law No } 32 \text { of } 2014 \\
\text { on Marine Affairs }\end{array}$ \\
\hline $3 r d$ & $\begin{array}{l}\text { Indonesia as the } \\
\text { GMF paradigm }\end{array}$ & $\begin{array}{l}2014 \text { until now } \\
\text { (2020) }\end{array}$ & $\begin{array}{l}\text { The new Indonesian } \\
\text { Ocean Policy }\end{array}$ & $\begin{array}{l}\text { Law No } 16 \text { of 2017on } \\
\text { Indonesian Ocean Policy }\end{array}$ \\
\hline
\end{tabular}

Nevertheless, the GMF vision also underlines Indonesia's view as an international promoter of peace. One of the IOP programmes on defence and security is aimed at enhancing Indonesia's participation in regional and international cooperation on maritime defence and security. On maritime diplomacy, the IOP explicitly states that Indonesia must play a leading role in various maritime cooperation initiatives at regional and global levels. ${ }^{31}$

\section{Indonesian Ocean Policy Related to Regional and Global Ocean Governance}

\section{A. IOP vis-a-vis Regional Initiatives}

Law No. 16 of 2017 states that the Vision of GMF needs to pay comprehensive attention to the relations between countries in Asia as well as various initiatives in 
the region such as the ASEAN Community, for instance, One Belt One Road of the Republic of China, Act-East of India, and RE-Balance of America. ${ }^{32}$ The Vision of GMF has links with various initiatives between countries because it is observed that global development is influenced by the ambitions of countries with great economic power to increase their influence with international cooperation. ${ }^{33}$

\section{The Belt \& Road Initiative}

In 2013, Chinese President Xi Jinping announced a new initiative, the 21st century Silk Road Initiative, popularly known as the Belt and Road Initiative ("BRI"). The Chinese government hopes to improve the global economy by promoting trade, cultural and technological exchange among Eurasian countries. To support this idea, the Chinese government is actively promoting infrastructure development, including highways and railways, across Eurasia so as to increase trade and improve logistics networks among the participating countries. There are around 60 countries expressing their interest in the BRI, which together represent more than half of the global population and around one-third of global GDP. ${ }^{34}$

The Initiative will certainly impact both Indonesia and China. China's BRI and the GMF both want to build a maritime infrastructure path for trade. One Road refers to the 21st century's iteration of the Maritime Silk Road or a sea-based silk route connecting China with Southeast Asia, South Asia, Africa, the Middle East and Europe. The BRI might be perceived as China's initiative to re-activate the historic Silk Road as the major route of China's trading activities with its neighbouring countries by implementing advanced technology and more efficient transportation costs. Along this Road, Indonesia has a very strategic position in this maritime connectivity. ${ }^{35}$

The BRI is significant from the Indonesian perspective. It provides a good opportunity to develop Indonesia's connectivity and infrastructure and to strengthen its position in the global market. Indonesia is the largest archipelagic state in the world, situated in a strategic location linking the Pacific and Indian Oceans. Ideally, Indonesia should be able to leverage this strategic geographic location to its own advantage and national interests. ${ }^{36}$ The BRI is in line with national interests enshrined

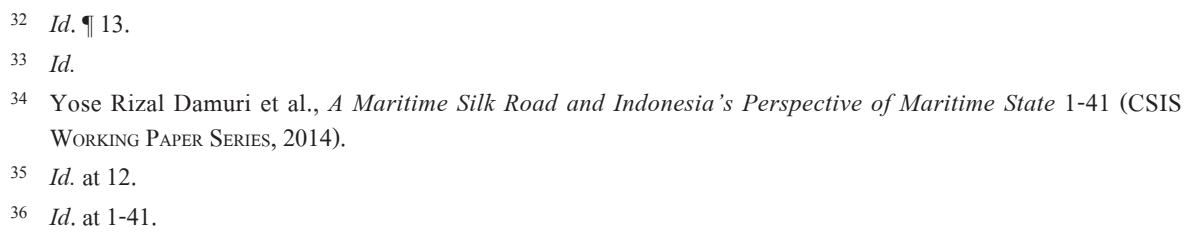


in the vision of GMF. This is related to maritime connectivity and economy. The development of maritime infrastructure is expected to improve the connectivity of maritime routes throughout the archipelago, which in turn will benefit Indonesia's maritime economic activities.

\section{Open and Free Indo-Pacific}

The Indo-Pacific concept has been around at least since August 2007, when the Japanese prime minister, Shinzo Abe, in a speech to the Indian parliament, first proposed drawing a strategic link between the Indian and Pacific oceans, "the confluence of the two seas," to develop cooperation aimed at ensuring a "free and open" Indo-Pacific region for international public goods. ${ }^{37}$

Indonesia has assumed a leading role in pushing ASEAN to actively participate in the discourse on this new "Indo-Pacific" strategic concept. Because Southeast Asia is located at the geographic midpoint between the Indian and Pacific oceans and all the lands around and within them, ASEAN must, in Jakarta's view, continue to retain its centrality in the evolving the Indo-Pacific construct. ASEAN's centrality is essential in ensuring the development of a truly open, transparent and inclusive Indo-Pacific which will try to bridge rather than accentuate differences. Jakarta's interest in the Indo-Pacific concept is also related to the President Jokowi's policy of establishing Indonesia, an archipelagic state, as a GMF by leveraging its location at the intersection between the Indian and Pacific oceans into greater than a mere physical presence. The general widening (not shifting) of focus from Asia-Pacific to Indo-Pacific pays more attention to the interconnecting oceans and helps to ensure that current and successive Indonesian administrations will continue to be attentive to the country's maritime domain. $^{38}$

At the ASEAN Summit meeting in Singapore onNovember 11, 2018, President Joko Widodo spoke of the concept of the Indo-Pacific as an open, transparent and inclusive initiative in accordance with international law and the ASEAN centrality. He said that the Indo-Pacific concept is in harmony with the national policy of GMF, in which an integrated collaboration in the maritime field is needed between the Indian Ocean and the Pacific Ocean. ${ }^{39}$

37 F. Heiduk \& G. Wacker, From Asia-Pacific to Indo-Pacific Significance, Implementation and Challenges 9 (SWP Research Paper, July 2020).

38 Dewi Fortuna Anwar, Indonesia and the ASEAN outlook on the Indo-Pacific, 96(1) InT'L AfF. 111-29 (2020).

39 Andre Notohamijoyo, Indonesia's Strategic Role in Indo-Pacific Cooperation, Ministry of Marine Affairs and Fisheries of the Republic of Indonesia [Peran Strategis Indonesia Dalam Kerjasama Indo-Pacific, Kementerian Kelautan Dan Perikanan Republik Indonesia] (Feb. 8, 2019), https:/kkp.go.id/artikel/8872-peran-strategis-indonesia-dalamkerjasama-indo-pacific. 
The ASEAN Outlook on the Indo-Pacific is an affirmation of ASEAN's role to maintain peace, security, stability and prosperity in the Indo-Pacific region, which includes the Asia Pacific and Indian Ocean. This outlook emphasises an open and inclusive approach to dialogue and cooperation in areas that are ASEAN priorities, namely maritime development, economics, connectivity and achievement of Sustainable Development Goals ("SDGs"). The Indo-Pacific concept which is an initiative of Indonesia prioritises the ASEAN priority cooperation, including the fields of SDGs, maritime interests, economics and connectivity. ${ }^{40}$

\section{Act East}

India's "Act East" policy is a diplomatic initiative to promote economic, strategic and cultural relations with the vast Asia-Pacific region at different levels. The policy was initiated by Indian Prime Minister Narendra Modi at the 9th East Asia Summit in November 2014 and was elaborated as a substitute for the "Look East" policy, which has been in place for more than two decades. According to Modi, "Act East" means that India is ready to play a more active role in the region. ${ }^{41}$ Indonesia and India share the same vision on maritime interests: the Indonesian government with a vision of GMF, while India with the "Act East" Policy. Based on the similarity of these two visions, both countries work and discuss the dynamics of the strategic environment in the waters of Southeast Asia together. ${ }^{42}$

\section{US-China Re-Balancing}

GMF can be interpreted as Indonesia's geopolitics, meaning that Indonesia can further maximise its geographical position to align with other powers in the region. Today, China and the US compete with each other to seize influence in the IndoPacific region. The common interests of both countries are to secure shipping routes and access to markets and resources in the Indo-Pacific region. Indonesia should be able to take advantage of its geographical location in lieu of its national interest. ${ }^{43}$

40 See Indonesia's Central Role in the Asean Outlook on Indo-Pacific Peran Sentral Indonesia pada Asean Outlook on Indo-Pacific [Kementerian Luar Negeri Republik Indonesia] (Aug. 20, 2019), https://kemlu.go.id/portal/id/read/539/ berita/peran-sentral-indonesia-pada-asean-outlook-on-indo-pacific.

41 Uttara Sahasrabuddhe \& Chaitanya Mallapur, Modi's Strategic Foreign Policy Vision: A Glass Half Full, Diplomat, May 17, 2017, https://thediplomat.com/2017/05/modis-strategic-foreign-policy-vision-a-glass-half-full.

42 Redaksi Asiatoday, The synergy between Indonesia and India strengthens the ocean axis [Sinergi Indonesia dan India perkuat poros maritime], AsIA TODAY, June 8, 2020, https://asiatoday.id/read/sinergi-indonesia-dan-india-perkuat-porosmaritim.

43 Dewi Fortuna Anwar, An Indonesian Perspective on the U.S. Rebalancing Effort toward Asia, The National Bureau of Asian Research (Feb. 26, 2013), https://www.nbr.org/publication/an-indonesian-perspective-on-the-u-s-rebalancingeffort-toward-asia. 
Indonesia needs monetary investment to improve infrastructure such as ports and strengthen domestic industries that can create jobs. Indonesia should be able to align with China economically to improve maritime infrastructure. In addition to building marine infrastructure, another important aspect to become a GMF is maritime security. Further, safeguarding Indonesia's sovereignty and maritime wealth is a government responsibility to maintain maritime safety and security. ${ }^{44}$ Indonesian leaders describe the geo-strategic shift to Asia that the US-China rivalry reflects as an opportunity for Indonesia. This paradigm shift represents a core foreign policy ambition of Jokowi's government to establish Indonesia as a "global maritime fulcrum" and rests on the increasing importance to global commerce of maritime traffic through Indonesia between the Pacific and Indian oceans. ${ }^{45}$

\section{B. Indonesian Ocean Policy related to Global Ocean Governance}

Recently, the international community is paying attention to global ocean governance issues. Ocean governance is the integrated conduct of policy, actions and affairs regarding the world's oceans to protect the ocean environment, utilise coastal and marine resources sustainably, and conserve its biodiversity. There are three elements of ocean governance, namely: (1) Legal Basis; (2) Institutional Framework; and (3) Implementation Mechanism. ${ }^{46}$

Global ocean governance must be supported by national ocean governance. Indonesia, as an archipelago State, has an ocean policy to support the goal of ocean governance. The three elements comprising the policy can be described in detail as follows: First, at the national level, the legal basis of the implementation of ocean governance in Indonesia is Law No. 17 of 1985 on the UNCLOS ratification, Law No. 32 of 2014 on Maritime Affairs, and Presidential Regulation No. 16 of 2017 on Indonesian Ocean Policy. Second, on the institutional framework aspect, the Indonesian government formed the Coordinating Ministry for Maritime Affairs based on Presidential Regulation No. 10 of 2015. The Ministry has the function of coordinating and synchronizing the formulation, determination and implementation of Ministry/Institution policies related to maritime issues, to strengthen maritime

44 L. Morris \& G. Persi Paoli, A Preliminary Assessment of Indonesia's Maritime Security Threats and Capabilities, RAND (2018).

45 N. Hamilton-Hart \& D. McRae, Indonesia : Balancing the United States and China, Aiming for Independence, in EMERging Partnerships IN South-East Asia (2015), https://www.usindo.org/assets/up/2015/12/Indonesia-BalancingUS-and-China-November-2015-MacArthur-Indonesia-ONLINE.pdf.

46 F. Bailet, Ocean Governance: Toward an Oceanic Circle, https://www.un.org/depts/los/convention_agreements/ convention_20years/presentation_ocean_governance_frbailet.pdf. 
nations and manage maritime resources. The relevant ministry is also responsible for coordinating with other coordinating ministries so as to produce an integrated evaluation report to recalibrate future maritime policies. Its two primary roles highlighted by the regulation would also mean expanding the pool of human resources with various backgrounds, expertise and skills ranging from economics, engineering and development, to defence and education. ${ }^{47}$

Second, based on Presidential Regulation No. 71 of 2019, a Coordinating Ministry for Maritime Affairs and Investment was formed which had the task of coordinating, synchronising and controlling the affairs of the Ministry in the administration of maritime affairs and investment. ${ }^{48}$

Third, for implementing the IOP, the Indonesian government issued a regulation of the Coordinating Ministry of Maritime Affairs No. 1 of 2018 on the guidelines for monitoring and evaluating the 2016-2019 IOP's Action Plan. ${ }^{49}$ This action plan implement the five priority programs of IOP as follows: (1) Maritime Diplomacy; (2) Maritime Industry and Sea Connectivity; (3) Natural Resources and Marine Services Industry and Marine Environment Management; (4) Maritime Defense and Security; and (5) Maritime Culture. ${ }^{50}$

The IOP's plan action consist of 303 program. Out of 303 programs in the Plan of Action of the IOP, 290 have reached $(95,71 \%)$ and 13 programs have not reached $(4.29 \%)$. To date, the government is preparing the Plan of Action of the IOP for 2020-2024. ${ }^{51}$ The IOP is in line with the SDGs road map which creates a framework to regulate and protect marine and coastal ecosystems from pollution from land, as well as making them aware of the impacts of ocean acidification. At the international level, Indonesia has a leading role in the sustainable oceans policy through the following pillars.

\section{a. The Our Ocean Conference (OOC) 2018}

The Conference focuses on efforts to achieve targets under SDG 14. The main areas

47 Supra note 27.

48 Presidental Regulation No. 71 of 2019 [Peraturan Presiden Republik Indonesia Nomor 71 Tahun 2019], https://jdih. kemlu.go.id/ildis/www/storage/document/Salinan\%20Perpres\%20Nomor\%2071\%20Tahun\%202019\%20.pdf.

49 Kemenkumham, State Gazette of the Republic of Indonesia [Berita Negara Republik Indonesia], http://ditjenpp. kemenkumham.go.id/arsip/bn/2018/bn135-2018.pdf. See also Implementation Guidelines-Monitoring-EvaluationAction Plan-Indonesian Marine Policies [pedoman pelaksanaan-pemantauan-evaluasi-rencana aksi-kebijakan kelautan indonesia], https:/jdih.maritim.go.id/cfind/source/files/abstrak-permenko/ABSTRAK\%20PERMENKO\%20NO $\% 20$ 1\%20TAHUN\%202018.pdf.

50 Id.

51 Coordinating Ministry for Maritime Affairs and Investments Compiles Action Plan for Indonesian Maritime Policy Phase II Year [Kemenko Marves Susun Rencana Aksi Kebijakan Kelautan Indonesia Tahap II Tahun 2020-2024] (July 22, 2020) https://maritim.go.id/kemenko-marves-susun-kebijakan-kelautan-indonesia-ii-tahun. 
of work at the Ocean Conference will be a political call to action and a segment on partnership dialogues and voluntary commitments. On the eve of the conference, more than 600 commitments had been received, with practical solutions to restore the health of the ocean. ${ }^{52}$

Indonesia's role in ocean governance at the international level includes hosting the Our Ocean Conference in 2018. This showcases Indonesia's leadership in the field of marine trade and fisheries, especially in dealing with threats to the Indonesian sea. The implementation of OOC in Indonesia is also a form of ocean diplomacy to show Indonesian legacy on ocean-related issues. There are at least six areas of action in the implementation of OOC, including sustainable fisheries; marine protected areas; marine pollution; climate change; sustainable blue economy; and maritime security. Different from the usual conference which only results in the signing of the MoU or agreement, the OOC 2018 produced a concrete commitment. ${ }^{53}$

\section{b. The Our Ocean Conference 2019}

On October 23-24, 2019, OOC was held in Oslo, Norway. Indonesia implemented most of its commitments in the OOC for the 2017 and 2018 periods. These commitments included sustainable fisheries, tourism, marine protection, reduction of marine pollution, safe marine networks, the prevention of ocean acidification, and understanding of the oceans and the future of the oceans. In an effort to protect the sea, Indonesia has succeeded in reaching the target of expanding its conservation area in 2018. Indonesia was also invited at the meeting in the United Nations Framework Convention on Climate Change (UNFCCC) in recognition of its standing as a good practitioner of eradicating Illegal, Unregulated, Unreported (IUU) Fishing, mainstreaming marine issues, and managing conservation areas. ${ }^{54}$

\section{c. Archipelagic and Island States (AIS) Forum}

Recalling its past maritime glory, Indonesia is ready to be a 21st century's leader in the sustainable maritime economy through the AIS Forum as the world's largest archipelagic nation. ${ }^{55}$ The AIS Forum, which Indonesia created in 2018 with support

52 World Meterological Organization, Ocean Conference puts spotlight on life below water (June 5, 2017), https:// public.wmo.int/en/media/news/ocean-conference-puts-spotlight-life-below-water.

53 See Indonesia seeking to ensure ocean commitments realised, JAKARTA Post, Oct. 27, 2018, https://www. thejakartapost.com/adv/2018/10/27/indonesia-seeking-to-ensure-ocean-commitments-realized.html.

54 Imam Hamdi, Indonesia Bring Four New Commitments [Indonesia Bawa Empat Komitmen Baru di Our Ocean Conference], Tempo Co. (Oct. 27, 2019), https://tekno.tempo.co/read/1264892/indonesia-bawa-empat-komitmen-barudi-our-ocean-conference-2019.

55 Luhut Binsar Pandjaitan, RI to Play Leadership Role in Sustainable Maritime Economy, (Oct. 30, 2019), https:// 
from the United Nations Development Program (UNDP), brings together both developed and developing nations, which face similar challenges caused by climate change.

As an active member of the United Nations, Indonesia is fully committed to the SDG and the "Leave No One Behind" agenda. The AIS Forum and the successful development of a sustainable marine economy will significantly contribute to achieving these goals in both Indonesia and all AIS countries. Indonesia will continue to support the AIS Forum which brings together a grouping of like-minded countries and organizations to tackle the threat of climate change. Through this forum, Indonesia also strives to protect the ecological rights of small islands and archipelagic states that bear the biggest brunt of climate change.

GMF can be realised if there are precise, effective and competitive policies and programs. These programs of maritime development are widespread within various ministerial and non-ministerial government institutions. Therefore, the National Document of the Indonesian Ocean Policy should ideally synergize and harmonize all ocean development programs to be more focused and targeted so that the results can be measured.

\section{d. Immediate Neighbour - The Need for Malaysia's Ocean Policy}

As Indonesia's immediate neighbour, Malaysia also proposed an Ocean Policy set by the Malaysian Federal Government in Putrajaya. It may, in one way or another, influence the region.

Malaysia's total sea area is almost twice of its landmass and contributes significantly to economic prosperity of the nation. ${ }^{56}$ Around 95\% of Indonesia's international trade via the oceans is estimated passing through Malaysia's most priceless sea route of navigation-the Straits of Malacca and Singapore. ${ }^{57}$ Aside from international shipping activities, petroleum and gas, coastal and marine tourism, fisheries, maritime insurance and other supporting activities are major revenue earners for Malaysia. ${ }^{58}$ These crucial maritime sectors are a catalyst in driving the Malaysian economy

www.thejakartapost.com/news/2019/10/30/ri-play-leadership-role-sustainable-maritime-economy.html.

56 S. Jagerroos, Assessment of Living Resources in the Straits of Malacca, Malaysia: Case Study, 4(1) J. AquACULture \& MAR. Biology (2016), https://medcraveonline.com/JAMB/assessment-of-living-resources-in-the-straits-of-malaccamalaysia-case-study.html.

57 M. Mohd Rusli, The application of compulsory pilotage in straits used for international navigation: A study of the straits of Malacca and Singapore, 3 Asian PoL. \& PoL'y (2011).

58 Tan Kim Hooi, Natural Resources Exploitation and Utilisation, in Profile of the Straits of Malacca: Malaysia's Perspective 75 (H. Ibrahim \& Hairil Anuar Husin eds., 2008). 
towards a fully developed nation. ${ }^{59}$ As Malaysia relies on the sea for its economic growth and sustainability, it had to formulate an ocean policy to ensure that there is a balance between economic exploitation and environmental protection of Malaysia's maritime space. ${ }^{60}$ Since early 2000, the draft of the Malaysia's Ocean Policy has been developed. The importance of the ocean sector to nation's well-being requires that the approaches that have been largely inherited from the past be revisited towards establishing anticipatory, coordinated, adaptive and directed responses to new challenges and opportunities at sea. Recognising this, the Government prepared a draft National Ocean Policy (NOP). It is envisaged to provide an essential framework to manage ocean resources in an inclusive and sustainable manner. ${ }^{61}$

Unfortunetly, however, the draft ocean policy that never really came into being and therefore could consider developing an ocean policy along the following lines:

(1) Promotion of integrated and sustainable management of natural resources and ecosystems in a holistic and cross-sectoral manner to support, among others, economic, social and human development, while facilitating ecosystem conservation, regeneration and restoration, and resilience in the face of new and emerging challenges. This would require an examination of the existing institutional framework;

(2) Strengthening of the science policy interface and evidence-based decisionmaking by combining dispersed information and assessments with building on existing assessments;

(3) Enhancing awareness among the public, especially the younger generation, of the significant contributions of the maritime sector in the national economy and of best practices to ensure synergy between conservation, management and sustainable use of coastal and marine resources, and promoting the maritime field as a viable and long-term career option for the younger generation;

(4) Enhancing education and training in marine science, technology and innovation to provide new human capability through better coordination, linkages and investment to meet current and future demand for qualified marine scientists and technologists;

(5) Supporting the growth and development of marine industries through expanded engagement between industry and marine research and innovation providers based on technology development and solutions, and improved partnerships;

\footnotetext{
59 Mohd Nizam Basiron, Tan Kim Hooi \& Zahaitun Mahani Zakariah, Wither Our Ecosystems?, 14 MIMA Bull. 4 (2007).

60 Cheryl Rita Kaur, New Challenges in Managing Oceans, Star (2019).

61 Cheryl Rita Kaur, Ocean Policy Development, Progress and Challenges in Malaysia http://eascongress.pemsea.org/ sites/default/files/file_attach/PPT-S1W3-D2-CherylKaur.pdf.
} 
(6) Taking stock of gaps in the implementation of existing policies, laws, conventions or treaties to improve environmental outcomes;

(7) Reviewing and adopting the draft National Ocean Policy as an overarching document and an approach to guide ocean governance in Malaysia; and

(8) Continued strengthening of regional and international cooperation to address the challenges related to common resources. ${ }^{62}$

As one of the key caretakers of the Straits of Malacca and Singapore with Indonesia, Malaysia needs to develop its Oceans Policy in order to be an influential maritime nation. ${ }^{63}$ However, there are the hurdles that have caused delays for Malaysia to develop its Ocean Policy:

(a) Its maritime sector is managed in a sectoral manner involving a tiered system structured around the federal and state government involving numerous ministries and agencies and local authorities;

(b) As such, the management system is dependent on each tier of governance causing (to a certain extent), complications in the implementation and enforcement of law as different agencies have different jurisdictions; and

(c) At the moment, there are more than 10 ministries and 31 maritime-related agencies entrusted with managing Malaysia's maritime space. ${ }^{64}$

In 2019, the former Malaysian Prime Minister, Mahathir Mohamad emphasised the need for Malaysia to have an ocean governance regime to avoid the overlapping of jurisdictions that could hamper the nation's maritime administration and management. ${ }^{65}$ This is needed to realise Malaysia's aspiration to be a true maritime nation. Therefore, there is a need for all maritime-related agencies to collaborate and consolidate necessary work processes through greater understanding, trust and open communication. Like Indonesia, Malaysia is still developing its ocean policy. It is hoped that the proposed policy would be a catalyst in driving the region toward a better future in maritime governance.

62 Id.

63 Saharuddin Abdul Hamid, National ocean policy - New opportunities for Malaysian ocean development, 25(6) MAR. POL'Y 427-36 (2001).

64 Datuk Dr. Ruhanie, Time to explore need for a national maritime agency, NEw STRAITs Time, July 23, 2019, https:// www.nst.com.my/opinion/columnists/2019/07/506667/time-explore-need-national-maritime-agency.

65 L. Andres, PM: Malaysian Maritime enforcement a fragmented affair; needs more coordination, New STRAITS TIMES, Mar. 27, 2019, https://www.nst.com.my/news/nation/2019/03/473325/pm-malaysian-maritime-enforcementfragmented-affair-needs-more. 


\section{Conclusion}

Indonesia has experienced three shifts in the paradigm of ocean governance: first when it released the Djuanda Declaration in 1957, which resulted in the concept of archipelagic outlook; second, the shift from a land-to ocean-based development focus; and third, the emerging vision of Indonesia as GMF. The IOP becomes a comprehensive reference for the realization of Indonesia as the GMF and for good ocean governance. The IOP is in line with the target of the SDG 14 entitled, "Life below Water and The Vision Our Ocean, Our Legacy." The IOP synergizes with regional initiatives such as the BRI, Act East, the US Rebalance and Indo-Pacific. In addition, Indonesia has an active role in international fora that are committed to safeguarding the world's seas as the future. An ocean policy is necessary for Malaysia as Indonesia's neighbouring country complement Indonesia and the region to realize enhanced ocean governance. 